\title{
渡口一西昌地区昔格达层沉积物的 热发光年龄测定
}

\author{
许学议串曹阴
}

(中国科学院地质研究所, 北京)

作者近两年来在研究渡口-西昌地区地壳稳定性时, 对年龄尚存争议的昔格达层归属问 题, 进行了初步探讨. 本区广泛分布昔格达层, 最初, 常隆庆先生称其为“浑且层”,划为第三纪 上新世; 后来袁复礼教授 (1938)改称为“昔格达层”, 并于 1958 年将其划为第四纪中期或晚期 的冰期湖相纹泥类型 ${ }^{[1,2]} ; 1966$ 年杨理华等人及 1977 年国家地震局西南烈度队, 将昔格达层划 分为下更新统 ${ }^{[3]}$. 本文报道利用热发光方法测定其沉积年代的初步结果, 以及几点认识.

热发光年数测定的依据是, 利用岩石、矿物和沉积物中有明显受热事件或外力作用(物理 和化学风化、机械搬运、阳光曝晒等)事件的标本 ${ }^{[4,5,6]}$, 测量其天然热发光量(事件后到现在累 积的热发光( ), 然后测其人工诱发热发光, 求其热发光感度和平均年剂量率. 根据下列公式

$$
T=\frac{N T L}{D_{r}},
$$

估算年龄值，式中 $T$ 代表年龄，NTL 代表天然累积热发光量， $D$ ，代表天然热发光等效剂量.

昔格达层是本区基岩风化破碎的产物, 由于风化、剥蚀、搬运、日光曝晒等地质作用, 陆源
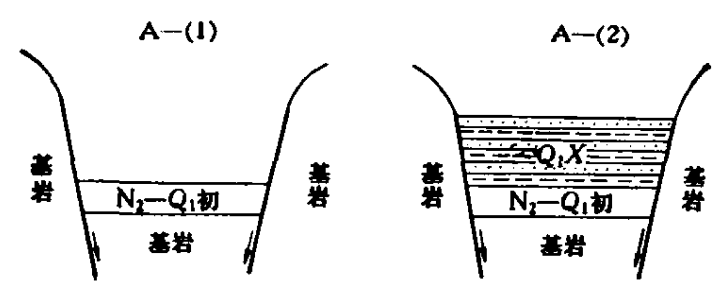

图 $1 \mathrm{~A}$ 第一期菖格达层堆积建造示意图

(1) $Q_{1}$ 中期(前 150 万年左右)元谋运动边界深断裂复活断陷杝地降;

（2） $Q_{1}$ 末至 $Q_{2}$ 初(前 120-90万年) 第一期昔格达层 $\left(Q_{1} X\right)$ 堆积阶段
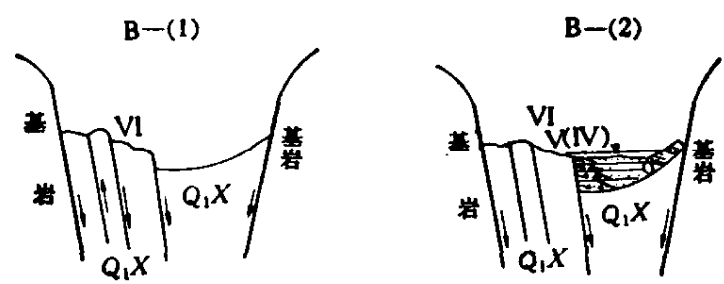

图 $1 \mathrm{~B}$ 第二期昔格达层堆积建造示意图

（1） $Q_{2}$ 中期(前60万年左右)构造运动边界深断裂复活、 $Q_{1} \times$ 发生断裂、断陷棈地沉洋加深;

（?） $\mathrm{Q}_{2}$ 晚期(前 50-35 万年)第二期昔格达层 $\left(\mathrm{Q}_{2} \mathrm{x}\right)$ 堆积阶段

木文1982年5月8 日收到。 
悴屑物中的铀、针等离子的逸出, 并在环境温度下退了火(使原来的热发光量减少乃至消失), 继之又在平静的地质环境中, 受其本身和围岩中放射性元素: 铀、针、钾的衰变以及宇宙射线 的辐射作用, 重新从零开始累积热发光量, 其热发光量的累积与时间成比例关系, 为热发光年 龄测定提供了依据. 在实测过程中也证实了这些可能性的存在.

试样采自各典型地段。精选各试样中 0.05 毫米的石英颗粒进行年龄测定,其结果见表 1 。 表 1 昔格达层沉积年代热发光法测定结果

\begin{tabular}{|c|c|c|c|c|c|c|c|}
\hline \multirow{2}{*}{ 样品编号 } & \multirow{2}{*}{ 取 样 地 点 } & \multirow{2}{*}{$\begin{array}{c}\text { 天然热发光等 } \\
\text { 效剂量 } \\
(\mathrm{R}) \\
\end{array}$} & \multicolumn{3}{|c|}{ 放射性 元 素* } & \multirow{2}{*}{ 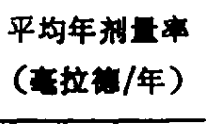 } & \multirow{2}{*}{$\begin{array}{c}\text { 年 } \\
\left(\times 10^{3} \text { 年 }\right)\end{array}$} \\
\hline & & & $U$ & i h & $\mathrm{K}, \mathrm{O}$ & & \\
\hline 北-3 & 黑沙河口南侧 & $6.2 \times 10^{4}$ & 0.0002 & 0.0015 & 2.13 & 143.685 & $380 \pm 38$ \\
\hline 北-5 & 兒宁北照壁崖下河边 & $6.6 \times 10^{4}$ & 0.0003 & 0.0015 & 3.25 & 178.105 & $330 \pm 17$ \\
\hline 北-6 & 雅若江里庄东沟 & $4.8 \times 10^{4}$ & 0.0003 & 0.0009 & 2.88 & 139.680 & $320 \pm 16$ \\
\hline 中-11 & 甸沙关公路旁小山梁上 & $1.64 \times 10^{5}$ & 0.0003 & 0.0009 & 2.69 & 135.785 & $1026.6 \pm 92$ \\
\hline 中-14 & 锦川罗七桥头 & $1.21 \times 10^{5}$ & 0.0001 & 0.0010 & 2.13 & 106.525 & $1008 \pm 150$ \\
\hline 中-20 & 德昌县砖厂旁 & $7.4 \times 10^{4}$ & 0.0002 & 0.0011 & 2.50 & 130.750 & $528 \pm 27.5$ \\
\hline 中-23 & 黄连关北 $2.5 \mathrm{~km}$ 鹿马村 & $8.4 \times 10^{4}$ & 0.0001 & 0.0007 & 1.75 & 83.315 & $930 \pm 87$ \\
\hline 中-31 & 大青梁子分水岭公路旁 & $7.0 \times 10^{4}$ & 0.0003 & 0.0011 & 3.63 & 165.335 & $388.8 \pm 34.9$ \\
\hline 中-33 & 西昌印海砖厂附近 & $5.8 \times 10^{4}$ & 0.0002 & 0.0010 & 3.01 & 136.025 & $386.6 \pm 35$ \\
\hline 南-10 & 华坪县城 & $7.3 \times 10^{4}$ & 0.0002 & 0.0011 & 2.63 & 133.375 & $486 \pm 49$ \\
\hline 南-12 & 野猪堂 III 级阶地后练基來 & $1.1 \times 10^{5}$ & 0.0001 & 0.0008 & 2.13 & 96.245 & $909 \pm 199$ \\
\hline 南-13 & 渡口炸药库附近 & $1.32 \times 10^{5}$ & 0.0001 & 0.0013 & 2.50 & 129.330 & $940 \pm 140$ \\
\hline 南-26 & 米易农场阶地基座 & $5.8 \times 10^{4}$ & 0.0002 & 0.0010 & 2.13 & 117.985 & $446 \pm 67$ \\
\hline 华古-2 & 渡口华坪公路旁(23 公里路柱) & $2.15 \times 10^{\prime}$ & 0.0003 & 0.0013 & 3.25 & 167.825 & $1190 \pm 62$ \\
\hline
\end{tabular}

表内仅标明采样的粗略位㽬(地点),地质剖面略。“三机部三所分析结果。

由表 1 可得出以下几点认识:

1. 热发光年龄测定结果表明：本区昔格达层分别形成于两个堆积建造期：第一期 $\left(\mathrm{Q}_{1} \mathrm{x}\right)$ 为下更新世末期, 即 90-120 万年左右; 第二期 ( $\left.Q_{2} \mathrm{x}\right)$ 为中更新世中期, 即 35-50 万年左右. 与野外地质考察相一致,但还须在今后的工作中应用其它测试手段相互印证.

2. 昔格达层的沉积历史和空间分布特征,与本区第四纪新构造块断差异运动有密切联系， 尤其受下更新世中期元谋运动(大约 150 万年左右)以及中更新世中期的新构造运动 (大约 60 万年左右)的制约 ${ }^{[3]}$ ，两期昔格达层分别在该两期构造断陷凹地中堆积形成(见图 $1 \mathrm{~A} 、 \mathrm{~B}$ ).

3. 昔格达层的热发光年龄测定，对于本区第四纪地层的对比、划分，以及对研究第四纪新 构造运动分期等, 可做为重要标志和依据,对研究该地区第四纪地质发展史有一定的意义.

[1]南京大学,中国第四纪冰川与水期问题,科学出版社, 1974, 50-75.

[2]地质力学研究所, 中国第四纪冰川地质文集, 地质出版社, 1977, 144-153, 164-177.：

[ 3] 国家地唇局西南烈度队,西南地区地震地质烈度区划探讨,地震出版社, 1977.

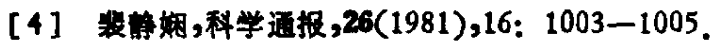

[5] 非静姆, 中国第四纪研究,5(1980), 1: 87-95.

[6] Wintle, A. G. \& Hwntor, D. J., Nature, 279(1979), 5715: 710. 